\title{
Competitive Advantage of Yemeni Export in the US Market
}

\author{
Saleh Mothana Obadi \\ Institute of Economics and Management, University of Economics in Bratislava, Bratislava, Slovakia \\ Email: ekonbadi@savba.sk
}

How to cite this paper: Obadi, S.M. (2017) Competitive Advantage of Yemeni Export in the US Market. Open Access Library Journal, 4: e3852.

https://doi.org/10.4236/oalib.1103852

Received: July 27, 2017

Accepted: September 24, 2017

Published: September 27, 2017

Copyright (c) 2017 by author and Open Access Library Inc.

This work is licensed under the Creative Commons Attribution International License (CC BY 4.0).

http://creativecommons.org/licenses/by/4.0/

\section{(c) (7) Open Access}

\begin{abstract}
This paper explores competitive advantage of Yemeni export in the market of the USA. Yemen has been placed under a special situation since the "Arab Spring" in 2011; therefore, our analyses study the eleven years prior to the war, between 2000 and 2011, and employ 2-digit SITCs to identify the various products for the selected study period. Balassa's index has been utilized to measure revealed competitive advantage (RCA). This approach is universally popular and is widely reported in literature; however, we are cognizant to the fact that this index may not be empirically relevant. Despite this drawback, Balassa's index has a feature for gross sectoral competiveness of the examined country or a group of countries. According to our empirical analyses using Balassa's index, we identified Yemen to have competitive advantages at the global level during international trade in the selected study period. The competitive advantage was restricted to a few groups of energy and non-energy commodities.
\end{abstract}

\section{Subject Areas}

Business Analysis, Business Theories, Economics, International Economics, International Relations

\section{Keywords}

Competitive Advantage, Yemeni Export, EU, USA

\section{Introduction}

Regardless the current catastrophic situation of Yemen, which until now is resulted by civil war, we have tried to analyze the international trade competitive advantage in the USA market during the period before the war. Comparative advantage is the term used to describe the tendency for countries to export those 
commodities that they are relatively adept at producing, vis-a'-vis the rest of the world. In other words, if a country can produce a good at a lower relative cost than other countries, then with international trade, that country should devote more of its scare resources to the production of the good (Addison-Smyth [1]). Through trade, that country can obtain other goods at a lower price (opportunity cost), in exchange for the good in which it has a comparative advantage.

Comparative advantage is a widely used concept in international trade since Ricardian classical theory of trade. Thus, according to the mentioned Ricardian theory, we can say that the stronger comparative advantage lead to larger gains from trade. In the same spirit with some simplification of variables Bella Balassa [2] has came with new term called revealed comparative advantage. Competitive advantage is widely believed by economists to be a key determinant of international production and trade patterns. But non-economists typically think otherwise. In business schools and business circles much greater emphasis is placed on the role of competitive advantage as a predictor of the economic fortunes not just of firms, but of nations as a whole (Neary, J.P. [3]).

The main objective of this paper is to examine competitive advantage of Yemeni export in the US market as a sectoral comparative analysis.

This paper is divided to main 5 sections, the second section, which is after the introduction, is focus on literature review, which has concerned in the more or less similar issues like our examined topic. The third section is about the methodology, methods and data used in our analysis and finally the empirical findings and conclusion are presented in the third and fourth sections respectively.

\section{Literature Review}

The comparative advantage or competitiveness of a country can be determined by employing various techniques. The most popular technique continues to be Balassa's index of "revealed comparative advantage"-Balassa, B. [2]. This technique has been in vogue for the past five decades and most scientific economic studies have used it. A few studies have used this method to measure a country's Revealed Comparative Advantage and Competitiveness vies á vis, other trade partners or trade blocks (Utkulu U. and Seymen D. [4], Obadi, S.M. [5] [6] and [7]). Similarly, a few other studies have used this index to quantify a country's revealed comparative advantage as a whole and its internal regions (Yue, C. and Hua, P. [8] and Clark, D. P. et al. [9]).

Balassa B. and Noland M. [10] used a modified method of Balassa's index in their paper "Revealed comparative advantage in Japan and the USA."In this study they surveyed the changing comparative advantage scene in Japan and USA. They measured RCA for 57 primary and 167 manufactured product categories and classified all their products into 20 commodity groups. They noted a drastic change in Japanese pattern of specialization during 1967-1983, when the Japanese shifted from unskilled labor intensive goods to human capital intensive products. During this same period, its comparative advantage increased in natu- 
ral resources intensive products. However, the USA continued to retain its specialization in physical and human capital intensive goods, with increase in its comparative advantage for natural resources intensive products. Both countries were observed to have higher comparative advantage for high technology products.

Bhattacharyya, R., [11] too used the RCA index in his study. He used the index to study the comparative advantage of India in vegetable, fruits and flower trade in the Asian, EU and North American (USA \& Canada) markets as compared to selected other South East Asian countries. Serin, V. \&Civan A., [12] conducted a similar study in Turkey for tomato, olive oil, and fruit juice industries. They analyzed the influence in the EU market for 1995-2005. Fertö, I. and Hubbard, L.J. [13] investigated the competitiveness of Hungarian agriculture in relation to that of the EU. Their study used four indices to measure comparative advantage for the period 1992 to 1998. Muendler, M. A., [14] examined Brazilian agriculture, specifically mining and manufacturing sectors, between 1986 and 200. He applied a correlation between the comparative advantage series and trade-related variables.

Most studies used RCA index as a measure of international specialization. Only a few have used it as a measure of competitiveness or competitive advantage. This study uses this index as a measure of competitive advantage (CTA). Nevertheless, competitiveness has a wider platform than international specialization. Usually, competitiveness is reviewed in the context of firm or competitive advantage of nations. Such an approach was pioneered by Porter, M. E. [15] and others.

Balassa index is widely popular for identification of international trade specialization or sectoral competitiveness; however, its appropriateness is under debate. Literature abounds with several other alternative indices and methods.

Most critics of Balassa's index, including Leromain, E. and Orefice, G. [16], have tried to construct a "New Revealed Comparative Advantage Index". They noted that "Balassa's Index" (1965) was more popular in literature to measure country-sector Revealed Comparative Advantage. However, because it is measured on observed trade flows, it tends to mix up all the factors influencing trade flows. One of the major drawbacks is that Balassa's Index fails to isolate exporter-sector (ex-ante) specific factors, which are the source of comparative advantage in the spirit of the traditional trade model. Furthermore, Balassa's Index is noted to have some empirical distribution weaknesses, mainly time instability and poor ordinal ranking property (Yeats [17]; Hinloopen and Van Marrewijk [18]).

\section{Methodology and Data}

Several methods have been employed to determine whether or not a country has comparative advantage. "Balassa index" (1965) is one such popular method. This index takes into account the goods produced or exported, or the numbers em- 
ployed in each industry, relative to other countries. Although this is a widely accepted approach to analyzing trade data and comparative advantage, the definition and empirical adaptation of RCA are subject to controversies and thus some alternative measures now exist. Since we are interested in the revealed comparative advantage of Yemen with respect to the EU and USA, we measure RCA of Yemen on the global level as the comparator.

It is important to determine Yemen's comparative advantage because the international market is highly competitive. Comparative advantage is the term used to describe the tendency for countries to export those commodities that they are relatively adept at producing, Vis-a'-Vis the rest of the world. In other words, if a country can produce a good at a lower relative cost than other countries, then with international trade, that country should devote more of its scare resources to the production of the good, as discussed by Addison-Smyth [1]. Through trade, that country can obtain other goods at a lower price (opportunity cost) in exchange for the good in which it has a comparative advantage.

In simple terms, a country having a comparative advantage for the production of a particular good should be found to export a higher proportion of that good relative to other countries. Therefore, this study seeks to determine Yemen's comparative advantage by using international trade data to compare exports in particular industries with the rest of the world and particularly with the EU.

The formula (equation) to measure a country's revealed competitive advantage (RCA) is as follows:

$$
R C A i=\left(X i, c / \sum X i c\right) /\left(X i, w / \sum X w\right)
$$

where

$$
\begin{aligned}
& R C A i=\text { revealed competitive advantage for good } i . \\
& X i, c=\text { exports of good i by country } c \\
& \sum X i, c=\text { total exports by country } c \\
& X i, W=\text { world exports of good } i \\
& \sum X W=\text { total world exports }
\end{aligned}
$$

If $R C A i>1$, then country has a comparative advantage in good $i$.

If $R C A i<1$, then country has a comparative disadvantage in good $i$.

In simple terms, a country that has a comparative advantage in the production of a good should be found to export a higher proportion of that good relative to other countries. Therefore, this study seeks to determine Yemen's comparative advantage by using international trade data to compare exports in particular industries with the rest of the world and particularly with the USA.

Through applying the Equation (1) to Yemen, USA and world trade data, it is possible to identify the sectors and industries in which Yemen has a competitive advantage and has a potential to increase its export to the US market.

\section{Used data}

From the United Nations COMTRADE Database, it is possible to get a detailed breakdown of Yemeni merchandise exports and imports by SITC (United Nations' Standard International Trade Classification), which is the means by 
which exports are classified according to commodity type. There are nine headline SITC categories as shown in the box below.

These more detailed breakdowns are important, as there are a number of quite diverse categories within each broad SITC heading. In our analyses we will just use the 2 digits SITC for selected seven years from the period 2000-2011. The full list of sub-sectors is included in the Appendix, Table S1. Using this classification, it is possible to examine Yemeni trade patterns across a range of commodity types. For trade data for the rest of the world, the UN COMTRADE database was used, with detailed data available up to 2011.

\section{Research Findings}

Following the contributions by Balassa, the present empirical analysis is based on the measurement of RCA. Since we are interested in the competitiveness of Yemen in the markets of the USA, we calculated an index of RCA presented in the earlier section with respect to the EU and USA as the comparator both on global and bilateral levels. On the global level, the global competitiveness of Yemen and the USA are compared assuming that Yemen, the USA are exporting to and importing from the world ${ }^{1}$. On the bilateral level, however, trade between Yemen and the USA are taken into account only.

In order to calculate RCA in the sense of global competitiveness of Yemen with respect to the USA, we used annual two-digit SITC Rev.3 data (61 product groups) covering Yemen's exports on the world level for the years 2000 and 2011 from the United Nations COMTRADE Database, and also annual two-digit SITC Rev.3 data (66 product groups) covering US exports on the world level for the same period of 2000-2011 from the United Nations COMTRADE Database also (Table 1).

This result is not surprising, as the commodities 33 SITC and 34 SITC account for more than $98 \%$ of total Yemeni exports.

It is clear from the results of the empirical analysis that in the selected years, Yemen has a revealed comparative advantage with respect to the USA in seven

Table 1. Coefficients of RCA of Yemeni international trade with respect to the USA in selected years.

\begin{tabular}{|c|c|c|c|c|c|c|c|c|}
\hline SITC code & Description & 2000 & 2002 & 2004 & 2006 & 2008 & 2010 & 2011 \\
\hline 03 & Fish, crustacean and molluscs, and preparations thereof & 0.0 & 0.0 & 0.0 & 0.0 & 10.0 & 0.0 & 0.0 \\
\hline 07 & Coffee, tea, cocoa, spices, and manufactures thereof & 9.2 & 7.2 & 7.2 & 5.6 & 351.7 & 7.8 & 0.0 \\
\hline 33 & Petroleum, petroleum products and related materials & 78.6 & 84.8 & 84.8 & 38.0 & & 169.1 & 6.4 \\
\hline 34 & Gas, natural and manufactured & 0.0 & 0.0 & 0.0 & 0.0 & 0.0 & 0.0 & 80.9 \\
\hline 71 & Power generating machinery and equipment & 0.0 & 0.0 & 0.0 & 0.0 & 3.6 & 0.0 & 0.0 \\
\hline 93 & Special transactions, commodity not classified according to class & 0.0 & 0.0 & 0.0 & 0.0 & 5.1 & 0.0 & 0.0 \\
\hline 96 & Coin nongold noncurrent & 5.0 & 0.0 & 0.0 & 0.0 & 0.0 & 0.0 & 0.0 \\
\hline
\end{tabular}

Source: Author's calculation base on UN COMTRADE Database, [17]

${ }^{1}$ Revealed Comparative Advantage and Competitiveness: Evidence for Turkey vis-à-vis the EU/15, see Utku Utkulu and Dilek Seymen [4] and for a similar empirical study of Hungary vis-à-vis the EU, see Fertö and Hubbard [13]. 
commodities from about fifteen commodities Yemen exports to the USA. However, in five commodities Yemen has comparative advantage only in one year from seven selected years. Some of these commodities were not exported in the other years and others (for example Gas, natural and manufactured (SITC 34) were exported for the first time. The highest levels of RCA of Yemen in the selected years were in the petroleum and petroleum products (SITC 33), Gas, natural and manufactured (SITC 34) and Coffee, tea, cocoa, spices, and manufactures thereof (SITC 07).

\section{Conclusions}

One of the characteristics of the last international economic crisis is its negative impact on all economies in all world regions. The impact was either directly or indirectly. The impact on Yemeni economy as on almost economies of developing economies was indirect-through the trade flows. The impact on Yemeni export during the deep crisis (2008-2009) was huge in relative to Yemeni small economy. Thanks to the launch of exporting the Yemeni natural gas (LNG), the Yemeni total export has recovered in 2010 and 2011.

Indeed, the global trading system, whilst offering opportunities, is by no means perfect. It gives inadequate attention to the specific needs and vulnerability of poor states (Yemen being one of them), which face special disadvantages associated with poor industrial infrastructure, remoteness, which has led to inappropriate implementation time frames. In spite of otherwise declared, problems for Yemeni export also arise due to the non-tariff barriers that are applied by many countries under the guise of quality standards and quarantine procedures. Lack of capacity and facilities in testing and accreditation has led to legitimate Yemen's exports being sidelined, and has allowed the entry of sub-standard imports "dumped" on the Yemen market.

For increasing the competitiveness of the Yemeni products and then exports, there are a number of things that should be done, starting from the political reforms, solving the political questions and democratization of the society, stabilization of the security situation in the country, then reduction of administrative bureaucracy and corruption from all economic life, then drawing an effective economic and trade policy which emphasized on the export promotion and generating a competitive and fairly business environment. On the other hand, building the effective institutions for inspections is not only for products of export, but also for imported products.

So, from this study it implies that, presently the export possibilities to the USA are occurred, in addition to the known export commodities, as follows:

1) Petroleum, petroleum products and related materials,

2) Gas, natural and manufactured,

3) Fish, crustacean and molluscs, and preparations thereof,

4) Coffee, tea, cocoa, spices, and manufactures thereof. 


\section{Funding}

This paper is supported by scientific project VEGA No.1/0654/16.

\section{References}

[1] Addison-Smyth, D. (2005) Ireland's Revealed Comparative Advantage. Quarterly Bulletin, 1, 2005. https://core.ac.uk/download/files/153/6377720.pdf

[2] Balassa, B. (1965) Trade Liberalisation and Revealed Comparative Advantage. The Manchester School, 33. https://doi.org/10.1111/j.1467-9957.1965.tb00050.x

[3] Neary, J.P. (2003) Competitive Advantage versus Comparative Advantage. World Economy [Online], 26, 457-470 https://doi.org/10.1111/1467-9701.00532

[4] Utkulu, U. and Seymen, D. (2004) Revealed Comparative Advantage and Competitiveness: Evidence for Turkey vis-à-vis the EU/15. Economics Department, Dokuz Eylül University, İzmir.

[5] Obadi, S.M. (2004) Globalization and Competitiveness: A Comparative Analysis of Developing Countries vs. Industrial Countries. In: Westerfield, R.E., Ed., Current Issues in Globalization, Nova Science Publishers, Inc., New York, 25-40.

[6] Obadi, S.M. (2005) The External Trade between Yemen and EU and USA. A Journal of Yemen Studies Center and Research, 10, 311-395.

[7] Obadi, S.M. (2012) Yemen's Revealed Comparative Advantage vis-á-vis both the EU and the USA. Working Papers [EÚ SAV], č. 35, s. 1-49.

http://ekonom.sav.sk/uploads/journals/188_wp_35_obadi_s_m_2012.pdf

[8] Yue, C. and Hua, P. (2002) Does Comparative Advantage Explains Export Patterns in China? China Economic Review, 13, 276-296. https://doi.org/10.1016/S1043-951X(02)00073-1

[9] Clark, D.P., et al. (2005) Revealed Comparative Advantage Indexes for Regions of the United States. Global Economy Journal, 5, Article 2.

https://doi.org/10.2202/1524-5861.1033

[10] Balassa, B. and Noland, M. (1989) Revealed Comparative Advantage in Japan and the USA. Journal of International Economic Integration, 4, 8-22. http://e-jei.org/upload/1w100053.pdf

[11] Bhattacharyya, R. (2011) Revealed Comparative Advantage and Competitiveness: A Case Study for India in Agricultural Products. International Conference on Applied Economics. http://kastoria.teikoz.gr/icoae2/wordpress/wp-content/uploads/2011/10/003.pdf

[12] Serin, V. and Civan, A. (2008) Revealed Comparative Advantage and Competitiveness:A Case Study for Turkey towards the EU. Journal of Economic and Social Research, 10, 25-41. http://jesr.journal.fatih.edu.tr/jesr.serin.civan.pdf

[13] Fertő, I. and Hubbard, L.J. (2002) Revealed Comparative Advantage and Competitiveness in Hungarian Agri-Food Sectors. Institute of Economics Hungarian Academy of Sciences, Budapest, Discussion Paper No. 2002/8.

[14] Muendler, M.A. (2007) Balassa (1965) Comparative Advantage by Sector of Industry. Brazil 1986-2001. University of California, San Diego.

http://econweb.ucsd.edu/muendler/docs/brazil/br-compadv.pdf

[15] Porter, M.E. (1990) The Competitive Advantage of Nations. Harvard Business Review, 90, 73-93.

http://dl1.cuni.cz/pluginfile.php/50387/mod_resource/content/0/Porter-competitiv e-advantage.pdf 
https://doi.org/10.1007/978-1-349-11336-1

[16] Leromain, E. and Orefice, G. (2013) New Revealed Comparative Advantage Index: Dataset and Empirical Distribution. CEPII Working Paper No. 30 Jun 2013.

http://www.cepii.fr/PDF_PUB/wp/2013/wp2013-20.pdf

[17] United Nations COMTRADE Database (2016).

http://unstats.un.org/unsd/comtrade

[18] Hinloopen and Van Marrewijk (2001) Comparative Advantage, the Ranksize Rule, and Zipf's Law. Tinbergen Institute, Amsterdam, Netherland.

http://citeseerx.ist.psu.edu/viewdoc/download?doi=10.1.1.521.2916\&rep=rep1\&type $=\mathrm{pdf}$ 
Appendix:

Table S1. RCA of Yemen with respect to the USA on the bilateral level in selected years, by product group and \% changes in index.

\begin{tabular}{|c|c|c|c|c|c|c|c|}
\hline & 2000 & 2002 & 2004 & 2006 & 2008 & 2010 & 2011 \\
\hline 00 & 0.133 & 0.125 & 0.000 & 0.000 & 0.000 & 0.000 & 0.000 \\
\hline 03 & 0.183 & 0.136 & 1.674 & 0.194 & 10.019 & 0.308 & 0.000 \\
\hline 04 & 0.000 & 0.003 & 0.000 & 0.000 & 0.000 & 0.003 & 0.004 \\
\hline 07 & 9.177 & 7.153 & 33.652 & 5.598 & 351.676 & 7.817 & 0.330 \\
\hline 33 & 78.594 & 84.831 & 59.185 & 38.039 & 0.000 & 0.000 & 6.397 \\
\hline 34 & 0.000 & 0.000 & 0.000 & 0.000 & 0.000 & 169.063 & 80.855 \\
\hline 53 & 0.000 & 0.000 & 0.000 & 0.000 & 0.590 & 0.007 & 0.000 \\
\hline 65 & 0.000 & 0.000 & 0.001 & 0.000 & 0.000 & 0.000 & 0.000 \\
\hline 66 & 0.007 & 0.000 & 0.000 & 0.000 & 0.000 & 0.002 & 0.000 \\
\hline 71 & 0.007 & 0.000 & 0.000 & 0.000 & 0.440 & 0.000 & 0.000 \\
\hline 72 & 0.000 & 0.000 & 0.000 & 0.000 & 3.569 & 0.006 & 0.002 \\
\hline 73 & 0.000 & 0.000 & 0.000 & 0.000 & 0.082 & 0.000 & 0.000 \\
\hline 74 & 0.000 & 0.000 & 0.003 & 0.000 & 0.168 & 0.000 & 0.000 \\
\hline 75 & 0.000 & 0.000 & 0.034 & 0.000 & 0.021 & 0.002 & 0.006 \\
\hline 76 & 0.000 & 0.000 & 0.001 & 0.020 & 0.052 & 0.000 & 0.000 \\
\hline 77 & 0.000 & 0.000 & 0.007 & 0.000 & 0.000 & 0.000 & 0.000 \\
\hline 78 & 0.000 & 0.000 & 0.000 & 0.000 & 0.009 & 0.000 & 0.000 \\
\hline 83 & 0.000 & 0.000 & 0.008 & 0.000 & 0.055 & 0.084 & 0.012 \\
\hline 84 & 0.000 & 0.000 & 0.001 & 0.006 & 0.000 & 0.000 & 0.000 \\
\hline 85 & 0.000 & 0.000 & 0.000 & 0.000 & 0.241 & 0.011 & 0.001 \\
\hline 87 & 0.000 & 0.000 & 0.005 & 0.002 & 0.110 & 0.003 & 0.000 \\
\hline 89 & 0.097 & 0.012 & 0.095 & 0.010 & 0.000 & 0.000 & 0.000 \\
\hline 93 & 0.843 & 0.152 & 0.624 & 0.240 & 0.832 & 0.174 & 0.071 \\
\hline 96 & 5.000 & 0.000 & 0.000 & 0.000 & 5.148 & 0.088 & 0.001 \\
\hline
\end{tabular}

Source: Author's calculation based on UN COMTRADE Database [17]. 
Submit or recommend next manuscript to OALib Journal and we will provide best service for you:

- Publication frequency: Monthly

- 9 subject areas of science, technology and medicine

- Fair and rigorous peer-review system

- Fast publication process

- Article promotion in various social networking sites (LinkedIn, Facebook, Twitter, etc.)

- Maximum dissemination of your research work

Submit Your Paper Online: Click Here to Submit

Or Contact service@oalib.com 